\title{
COMPARISON OF FATIGUE CHARACTERISTICS FOR SOME SELEC- TED STRUCTURAL MATERIALS UNDER BENDING AND TORSION
}

\author{
M. KUREK, T. ŁAGODA
}

\author{
Opole University of Technology, Poland
}

\begin{abstract}
The paper presents a review of the multiaxial fatigue criteria including a ratio of normal and shear stresses. The paper also contains fatigue characteristics for bending and torsion of some selected constructional materials. The ratio of normal stresses to shear stresses was determined for the defined number of cycles $N_{f}$ in the range $5 \cdot 10^{4} \div 2 \cdot 10^{6}$. Moreover, from the performed analysis of fatigue equations and the relative difference $R$ it appears that materials can be divided into groups for which it is possible or it is not possible to apply the constant value of the considered ratio in the criteria including this ratio.
\end{abstract}

Keywords: fatigue characteristics, normal and shear stresses, constructional materials.

Most machines, devices and structures must be characterized by a very high life and reliability. However, determination of fatigue life is often difficult because it cannot be done with one equation. Numerical calculations allow to predict behavior of machine elements and structures under service loadings [1-21]. At present fatigue life is usually determined with analytic methods and computer simulations. This paper presents relations between the fatigue strength of some selected materials under pure bending and pure torsion, namely determination of the ratio of normal stresses to shear stresses. Many fatigue stress criteria include this ratio in their equations. In the criteria proposed by Tresca and Huber-Mises-Hencky assume 2 and $\sqrt{3}$ as values of this ratio, respectively.

The main aim of this paper is to determine relations between the fatigue life under bending and torsion for some chosen constructional materials. Next, the materials with no parallelism of characteristics for pure bending and pure torsion are determined. A model of fatigue life determination for such materials will be presented in future papers.

Criteria of multiaxial fatigue. A multiaxial fatigue criterion must include a substitute quantity allowing to compare multiaxial and uniaxial loadings. Owing to that, we are able to evaluate the influence of various complex loadings on fatigue life. If cyclic behaviour of the material under simple loadings is known, it is possible to assess influence of complex loadings on fatigue life. Even the oldest criteria of fatigue life determination include the following ratio

$$
B_{1}=\sigma_{a f} / \tau_{a f} .
$$

Such relationship is the criterion proposed by Gough and Pollard [7], pioneers of research work on bending and torsion. Relationships were modified by Nisihara and Kawamoto in 1941 [15]. Gough's criterion can be applied only for in-phase loadings. The further modification by Lee [9] includes phase shifts. In [12] you can find a general form of the multiaxial fatigue criterion for the high-cycle range. The equation assumes that fatigue damage is caused by a linear combination of normal and shear stresses on

Corresponding author: M. KUREK, e-mail: m.kurek@doktorant.po.edu.pl 
the critical plane. Findley [6] proposed the criterion based on observation of the planes of fatigue crack initiation in steels and aluminium alloys. Another criterion including the ratio $\sigma_{a f} / \tau_{a f}$ is the relationship presented by Stanfield, Guest and Stulen-Cummings [18]. In [21], Zenner and Lui presented the criterion where the equivalent stress was determined from the combination of the mean normal stresses $\sigma_{a}$ and shear stresses $\tau_{a}$. In [3], Carpinteri and Spagnoli presented a proposal based on the experimental criterion formulated by Gough. Achtelik [19] proposed the criterion for description of fatigue strength under loading by synchronously variable torsional and bending moments.

The basic relations between normal and static stresses allow to analyze bending and torsion and obtain new forms of the multiaxial fatigue criterion. Ogonowski [11] proposed the expression for elastic-plastic materials

$$
\sigma_{e g}(t)=B_{1} \max _{t}\left\{\tau_{\eta s}(t)\right\}+\left(2-B_{1}\right) \sigma_{\eta}(t) .
$$

This criterion is applied when the critical plane is influenced by shear stresses.

Walat [21] proposed the criterion for materials of intermediate properties (between brittle and elastic plastic).

$$
\sigma_{e g}(t)=\frac{4 \sqrt{3}+3 \sqrt{2} B_{1}}{3(\sqrt{3} \pm 1)} \sigma_{\eta}(t)+\frac{\sqrt{3}\left(3 \sqrt{2} B_{1}-4\right)}{3(\sqrt{3} \pm 1)} \tau_{\eta s}(t) .
$$

In this case the critical plane includes elements of covariance of normal and shear stresses. Some of multiaxial fatigue criteria including a ratio of normal and shear stresses are shown in Table 1.

Table 1. Some of multiaxial fatigue criteria including a ratio of normal and shear stresses

\begin{tabular}{|c|c|}
\hline Author & Criterion \\
\hline Gough and Pollard & $\sigma_{a e q}=\sqrt{\sigma_{a b}^{2}+\left(\frac{\sigma_{a f}}{\tau_{a f}} \cdot \tau_{a t}\right)^{2}}$ \\
\hline $\begin{array}{c}\text { Nisihara and } \\
\text { Kawamoto }\end{array}$ & $2\left(\frac{\tau_{a}}{\tau_{a f}}\right)^{2}+\left[1-\left(\frac{\sigma_{a f}}{\tau_{a f}}\right)^{2}\right]\left(\frac{\sigma_{a}}{\sigma_{a f}}\right)^{2}+\left[3-\left(\frac{\sigma_{a f}}{\tau_{a f}}\right)^{2}\right]\left(\frac{\sigma_{a}}{\sigma_{a f}}\right)=2$ \\
\hline Crossland & $\left(\sigma_{a 1}^{2}+\sigma_{a 2}^{2}+\sigma_{a 3}^{2}-\sigma_{a 1} \sigma_{a 2}-\sigma_{a 2} \sigma_{a 3}-\sigma_{a 3} \sigma_{a 1}\right)^{1 / 2}=$ \\
\hline Findley & $=\sqrt{3} \tau_{a f}-\left(\sqrt{3} \frac{\tau_{a f}}{\sigma_{a f}}-1\right)\left(\sigma_{1}^{\prime}+\sigma_{2}^{\prime}+\sigma_{3}^{\prime}\right)$ \\
\hline & $\sigma_{a e q}=n\left(k_{2} \sigma_{n, \max }+\tau_{\max }\right), \quad k_{2}=\frac{2-\frac{\sigma_{a f}}{\tau_{a f}}}{2 \sqrt{\frac{\sigma_{a f}}{\tau_{a f}}-1}}$ \\
\hline
\end{tabular}




\begin{tabular}{|c|c|}
\hline Lee & $\sigma_{a e q}=\sigma_{a b}\left[1+\left(\frac{\sigma_{a f}}{\tau_{a f}} \cdot \frac{\tau_{a t}}{\sigma_{a b}}\right)^{\alpha}\right]^{1 / \alpha}$ \\
\hline Matake & $\tau_{a e q}=\left(2 \frac{\tau_{a f}}{\sigma_{a f}}-1\right) \sigma_{n, \max }+\tau_{\max }$ \\
\hline Lassere i Froustey & $\sigma_{a}^{2}+\left(\frac{\sigma_{a f}}{\tau_{a f}}\right)^{2} \tau_{a}^{2}=\left(\sigma_{a f}-\alpha_{F} \sigma_{m}\right)^{2}$ \\
\hline Stulen i Cummings & $\sigma_{a e q}=\sigma_{1 a}-\left(\frac{\sigma_{a f}}{\tau_{a f}}-1\right) \sigma_{3 a}$ \\
\hline Carpinteri i Spagnoli & $\sigma_{a e q}=\sqrt{\sigma_{\max }^{2}+\left(\frac{\sigma_{a f}}{\tau_{a f}}\right)^{2} \tau_{a}^{2}}$ \\
\hline Zenner i Lui & $\sigma_{a e q}=\sqrt{a \sigma_{a}^{2}+b \tau_{a}^{2}}, a=\frac{1}{5}\left[3\left(\frac{\sigma_{a f}}{\tau_{a f}}\right)^{2}-4\right], b=\frac{1}{5}\left[6-2\left(\frac{\sigma_{a f}}{\tau_{a f}}\right)^{2}\right]$. \\
\hline
\end{tabular}

As for some materials, the coefficient $\mathrm{k}$ is stable, and the materials are characterized by parallelism of characteristics. In the case when

$$
B_{1}\left(N_{f}\right) \neq \sigma_{a f} / \tau_{a f}
$$

the solution of the algorithm for fatigue life assessment has not been found.

Comparison of fatigue characteristics for bending and torsion. The test results in the high-cycle regime were approximated by the regression equation for bending according to the ASTM recommendations 0 in the following form

$$
\begin{gathered}
\log N_{f}=A_{\sigma}+B_{\tau} \log \sigma_{a}, \\
\log N_{f}=A_{\sigma}+B_{\sigma} \log \sigma_{a} .
\end{gathered}
$$

For torsion the regression equation takes the form

$$
\log N_{f}=A_{\tau}+B_{\tau} \log \tau_{a},
$$

where $A_{\sigma}, B_{\sigma}, A_{\tau}, B_{\tau}$ - coefficients of the regression equation for bending and torsion, respectively.

The relations between the fatigue lives for pure bending and pure torsion of some constructional materials were determined according to the test results presented in [6$9,14-16,20]$. In this paper, also the value of the following ratio was also determined

$$
B_{1}\left(N_{f}\right)=\frac{\sigma_{a}\left(N_{f}\right)}{\tau_{a}\left(N_{f}\right)}
$$

After transformation of equations (5) and (6) we have:

$$
B_{1}\left(N_{f}\right)=10^{\log N_{f}\left(\frac{1-A_{\sigma}}{B_{\sigma}}-\frac{1-A_{\tau}}{B_{\tau}}\right)}
$$

Non-ferrous metal alloys. Brass $\mathrm{CuZn40Pb2} \mathrm{[9]} \mathrm{and} \mathrm{aluminium} \mathrm{alloys} \mathrm{D-30} \mathrm{[15]}$ and $\mathrm{AlCuMg1}$ [7] were considered. Chemical composition of the tested non-ferrous 
metal alloys are shown in Table 2. Coefficients of the regression equation according to Eqs. (5) and (6) for particular loading variants are shown in Table 3. Figs. 1 and 2 present the fatigue curves for pure bending and pure torsion of $\mathrm{CuZn} 40 \mathrm{~Pb} 2$ and $\mathrm{AlCuMg} 1$.

Table 2. Chemical composition of the tested non-ferrous metal alloys

\begin{tabular}{|c|c|c|c|c|c|c|c|c|}
\hline Mat & $\mathrm{Mg}$ & $\mathrm{Cu}$ & $\mathrm{Pb}$ & $\mathrm{Al}$ & $\mathrm{Zn}$ & $\mathrm{Mn}$ & $\mathrm{Fe}$ & $\mathrm{Si}$ \\
\hline$\overline{\mathrm{CuZn} 4}$ & - & $0.5 \ldots 0.6$ & $1 \ldots 0.35$ & 0.1 & rest & - & - & - \\
\hline AlCu4Mg1 [8] & $\ldots 1.0$ & $3.8 \ldots 4.8$ & - & rest & 0.5 & $0.4 \ldots 1.0$ & 0.7 & $0.2 \ldots 0.8$ \\
\hline D-30 [16] & 42 & 3.81 & - & rest & - & 0.44 & 0.38 & 0.35 \\
\hline
\end{tabular}

Table 3. Coefficients of regression equations for non-ferrous metal alloys

\begin{tabular}{|c|c|c|c|c|}
\hline \multirow{2}{*}{ Material } & \multicolumn{2}{|c|}{ Bending } & \multicolumn{2}{c|}{ Torsion } \\
\cline { 2 - 5 } & $A_{\sigma}$ & $B_{\sigma}$ & $A_{\tau}$ & $B_{\tau}$ \\
\hline $\mathrm{CuZn} 40 \mathrm{~Pb} 2[9]$ & 19.977 & -5.857 & 45.309 & -17.172 \\
\hline $\mathrm{AlCuMg} 1[7]$ & 21.806 & -7.027 & 19.939 & -6.868 \\
\hline $\mathrm{D}-30[15]$ & 30.538 & -10.753 & 25.385 & -9.174 \\
\hline
\end{tabular}

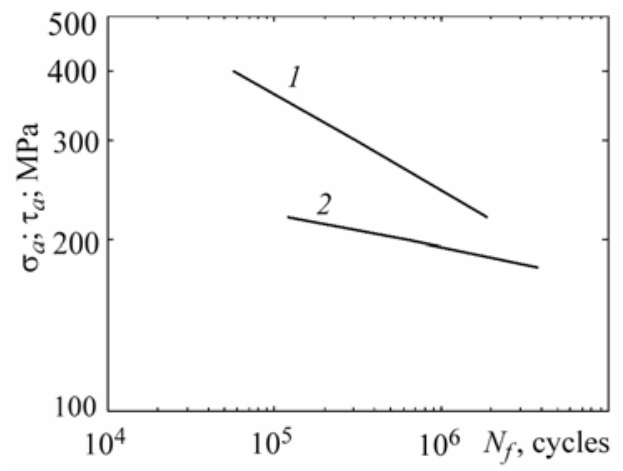

Fig. 1.

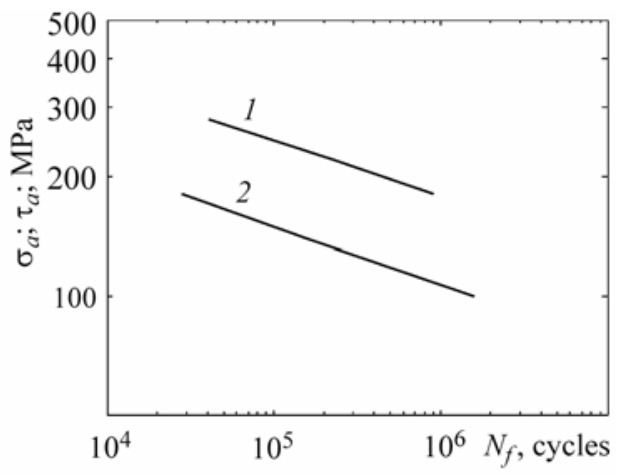

Fig. 2.

Fig. 1. Fatigue curves for pure bending and pure torsion for $\mathrm{CuZn} 40 \mathrm{~Pb} 2$ : $1-\log N_{f}=19.997-5.857 \log \sigma_{a} ; 2-\log N_{f}=45.309-17.172 \log \tau_{a}$.

Fig. 2. Fatigue curves for pure bending and pure torsion for AlCuMg1. $1-\log N_{f}=21.806-7.027 \log \sigma_{a} ; 2-\log N_{f}=19.939-6.868 \log \tau_{a}$.

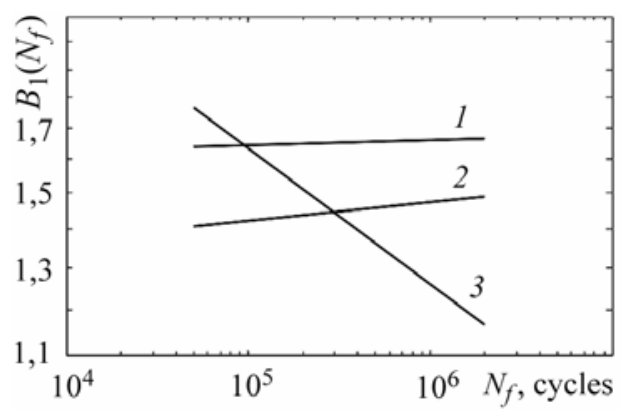

Fig. 3. Dependence of the ratio $B_{1}\left(N_{f}\right)$ on a number of cycles $N_{f}$ for non-ferrous metals. 1 - AlCuMg1; 2 - D-304; 3 - CuZn40Pb2.
Fig. 3 shows a relation between the ratio $B_{1}\left(N_{f}\right)$ and a number of cycles $N_{f}$ for non-ferrous metals.

The ratio $B_{1}\left(N_{f}\right)$ for both kinds of duralumin is constant, and its value for $\mathrm{D}-30$ varies from 1.407 to 1.492 , for $\mathrm{AlCu} 4 \mathrm{Mg} 1$ the ratio $B_{1}\left(N_{f}\right)$ takes the values $1.642 \div 1.665$. Stability of the ratio of normal stresses to shear stresses allows to apply a constant value of this ratio in fatigue criteria including it in their relationships. In the case of brass, the ratio $B_{1}\left(N_{f}\right)$ was not constant, and it could 
be expected after analysis of fatigue curves (Figs. 1 and 2) and coefficients of the curve slopes. As for brass, various values of $B_{1}\left(N_{f}\right)$ cause that it is not possible to apply a constant value of the ratio in fatigue criteria where the ratio is included.

Then, stability of $B_{1}\left(N_{f}\right)$ was determined by calculation of the relative difference $R$ expressed as

$$
R=\left|\frac{\left[B_{1}\left(5 \cdot 10^{4}\right)-B_{1}\left(2 \cdot 10^{6}\right)\right]}{B_{1}\left(5 \cdot 10^{4}\right)}\right| \cdot 100 \% .
$$

Analysis of the considered constructional materials is based on the assumption that a relative difference less than $10 \%$ qualifies the material as a material of the constant coefficient $B_{1}\left(N_{f}\right)$ in the given range of $N_{f}$.

Carbon steels. Iron-carbon alloys are unalloyed carbon steels because contents of other elements does not exceed the limit values defined. Carbon steels have got different structures depending on carbon contents. Coefficients of the regression equation for particular variants of loading are presented in Table 4.

Table 4. Coefficients of regression equation for carbon steels

\begin{tabular}{|c|c|c|c|c|}
\hline \multirow{2}{*}{ Material } & \multicolumn{2}{|c|}{ Bending } & \multicolumn{2}{c|}{ Torsion } \\
\cline { 2 - 5 } & $A_{\sigma}$ & $B_{\sigma}$ & $A_{\tau}$ & $B_{\tau}$ \\
\hline 982 FA [16] & 43.821 & -14.925 & 49.333 & -18.518 \\
\hline $5695[16]$ & 46.383 & -16.667 & 61.250 & -25.000 \\
\hline $0,1 \% \mathrm{C}^{1}[16]$ & 36.395 & $-12,346$ & 35.918 & -13.513 \\
\hline $0,1 \% \mathrm{C}^{2}[7]$ & 48.276 & -17.240 & 40.571 & -15.873 \\
\hline $0,4 \% \mathrm{C}^{3}[7]$ & 35.883 & -11.778 & 65.702 & -25.641 \\
\hline $0,4 \% \mathrm{C}[7]$ & 96.926 & -37.037 & 47.868 & -18.868 \\
\hline $0,9 \% \mathrm{C}[7]$ & 23.410 & -6.944 & 21.071 & -6.493 \\
\hline $\mathrm{S} 20 \mathrm{C}[5]$ & 20.846 & -6.173 & 18.364 & -6.061 \\
\hline $\mathrm{SC} 450[5]$ & 49.741 & -18.518 & 36.301 & -13.699 \\
\hline $\mathrm{S} 45 \mathrm{C}[5]$ & 25.294 & -7.936 & 25.807 & -9.174 \\
\hline $\mathrm{S} 45 \mathrm{C}-\mathrm{H}[5]$ & 34.555 & -11.111 & 38.473 & -13.513 \\
\hline $\mathrm{S} 45 \mathrm{C}-\mathrm{DA}[5]$ & 40.225 & -14.084 & 30.505 & -10.989 \\
\hline $\mathrm{Ck} 45[15]$ & 29.147 & -9.200 & 55.995 & -20.702 \\
\hline $\mathrm{C} 40[15]$ & 48.262 & -17.332 & 40.757 & -15.170 \\
\hline
\end{tabular}

${ }^{1}$ - full specimen; ${ }^{2}$ - holed specimen; ${ }^{3}$ - normalized.

Fig. 4 shows the dependence of the ratio $B_{1}\left(N_{f}\right)$ on a number of cycles $N_{f}$ for carbon steels. In order to obtain readable graphs, the considered steels were divided into two groups. Group 1 includes steels with the relative difference $R$ less than $5 \%$ (Fig. 4a). Group 2 contains steels with $R$ greater than $5 \%$.

Low-alloy steels. The test results obtained for steels S255 JO (former 18G2A) and S355JOWP (former 10HNAP) were considered. Fig. 5 presents the dependence of the ratio $B_{1}\left(N_{f}\right)$ on a number of cycles $N_{f}$ for steels S255 JO and S355JOWP. From Fig. 5 it results that in the case of steel S255 JO the ratio $B_{1}\left(N_{f}\right)$ is not constant in the range of a number of cycles $\left(5 \cdot 10^{4} \div 2 \cdot 10^{6}\right)$. This conclusion can be proved by determination of the relative difference for steel S255 JO (it is greater than 18\%). The considered ratio is constant for steel S355JOWP, where $R$ does not exceed 5\%. Finally, we can state that 
in the case of low-alloy steels the ratio $B_{1}\left(N_{f}\right)$ in the given range of a number of cycles can take similar or different values.
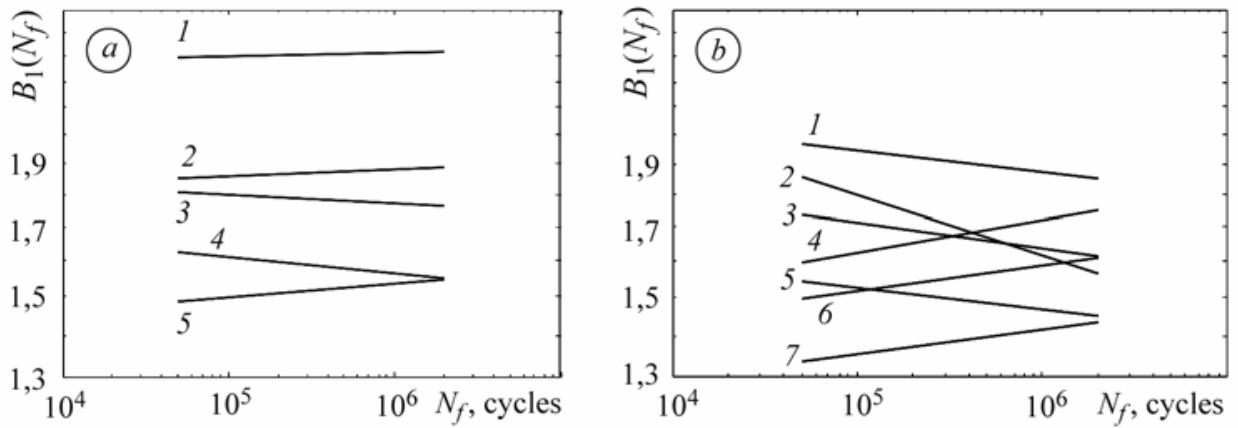

Fig. 4. Dependence of the ratio $B_{1}\left(N_{f}\right)$ on a number of cycles, $N_{f} . a$ : $R<5 \% ; 1-$ steel S20C; 2 - steel $0.1 \% \mathrm{C}$ full specimen; 3 - steel $0.1 \% \mathrm{C}$, holed specimen; 4 - steel $982 \mathrm{FA}$; 5 - steel $0.9 \%$ C. $b: R>5 \% ; 1$ - steel S45C; 2 - steel $5695 ; 3$ - steel $0.4 \%$ C normalized; 4 - steel 0.4\% C; 5 - S45C-H; 6 - steel S45C-DA; 7 - steel SC450.

Medium-alloy steels. Table 5 contains coefficients of regression equations for particular loading variants 16. Fig. 6 shows the dependence of changes of the ratio $k\left(N_{f}\right)$ on a number of cycles $N_{f}$ for nickel steels $3 \% \mathrm{Ni}, 3 \ldots 3.5 \% \mathrm{Ni}$, and chromium steels $\mathrm{CrV}, 42 \mathrm{CrMo} 4 \mathrm{~V}$.

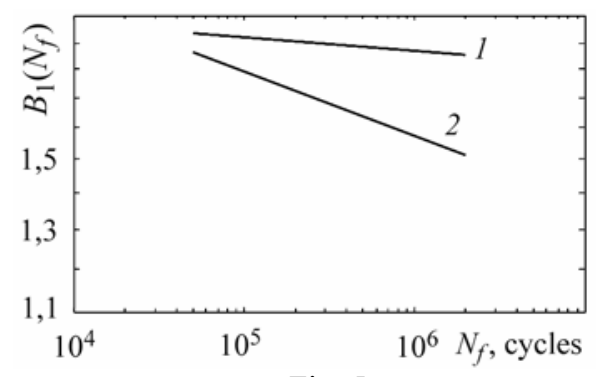

Fig. 5.

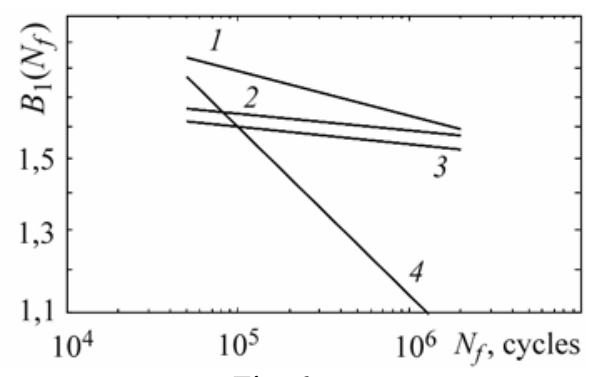

Fig. 6 .

Fig. 5. Dependence of the ratio $B_{1}\left(N_{f}\right)$ on a number of cycles $N_{f}$ for low-alloy steels. 1 - S355JOWP; 2 - S255 JO.

Fig. 6. Dependence of the ratio $B_{1}\left(N_{f}\right)$ on a number of cycles $N_{f}$ for medium-alloy steels. $1-3 \% \mathrm{Ni} ; 2$ - $\mathrm{CrV} ; 3-3 \ldots 3.5 \% \mathrm{Ni} ; 4-42 \mathrm{CrMo} 4 \mathrm{~V}$.

Table 5. Coefficients of regression equations for medium-alloy steels

\begin{tabular}{|c|c|c|c|c|}
\hline \multirow{2}{*}{ Material } & \multicolumn{2}{|c|}{ Bending } & \multicolumn{2}{c|}{ Torsion } \\
\cline { 2 - 5 } & $A_{\sigma}$ & $B_{\sigma}$ & $A_{\tau}$ & $B_{\tau}$ \\
\hline $3 \% \mathrm{Ni}[6]$ & 37.825 & -12.500 & 62.878 & -24.390 \\
\hline $3 \ldots 3.5 \% \mathrm{Ni}[6]$ & 39.354 & -12.658 & 44.219 & -15.625 \\
\hline $\mathrm{CrV}[6]$ & 55.418 & -18.868 & 68.478 & -25.840 \\
\hline $42 \mathrm{CrMo} 4 \mathrm{~V}[6]$ & 16.439 & -4.286 & 33.663 & -11.628 \\
\hline
\end{tabular}

High-alloy steels. Coefficients of the regression equations for particular loading variants are presented in Table 6. 
Fig. 7 shows the dependence of a change of the ratio $k\left(N_{f}\right)$ on a number of cycles $N_{f}$ for high-alloy steels. Similar problem concerning high-alloy steels was analyzed in [2].

Table 6. Coefficients of regression equation for high-alloy steels

\begin{tabular}{|c|c|c|c|c|}
\hline \multirow{2}{*}{ Material } & \multicolumn{2}{|c|}{ Bending } & \multicolumn{2}{c|}{ Torsion } \\
\cline { 2 - 5 } & $A_{\sigma}$ & $B_{\sigma}$ & $A_{\tau}$ & $B_{\tau}$ \\
\hline NiCr [6] & 76.923 & -22.544 & 27.027 & -80.538 \\
\hline 30 CrNiMo8 [5] & 27.536 & -8.049 & 69.578 & -24.622 \\
\hline $3.5 \%$ NiCr I [6] & 156.600 & -55.555 & 41.422 & -14.080 \\
\hline $3.5 \%$ NiCr I (hollowed) [6] & 30.731 & -9.259 & 213.000 & -83.333 \\
\hline $3.5 \%$ NiCr II [6] & 55.200 & -18.182 & 47.900 & 16.667 \\
\hline 35 NCD16 [12] & 31.953 & -10.030 & 44.510 & -15.080 \\
\hline
\end{tabular}

Cast irons. Cast iron is a casting alloy of iron, carbon and other elements containing from 2 to $3.6 \%$ of carbon in form of cementite or graphite. The following cast irons were subjected to tests under bending and torsion: Silal, Nicro Silal and IC2. Silal is an example of a brittle material, and Nicro Silal is a comparably plastic cast iron. The cast irons GGG40, GGG60 or GTS45 were considered under tension, compression and torsion [7, 14]. Fig. 8 presents the dependences of the ratio $B_{1}\left(N_{f}\right)$ on a number of cycles $N_{f}$ for some cast irons.

From Fig. $8 a$ and values of the relative ratio $R$ for the first group of cast irons it appears that the ratio $B_{1}\left(N_{f}\right)$ can-

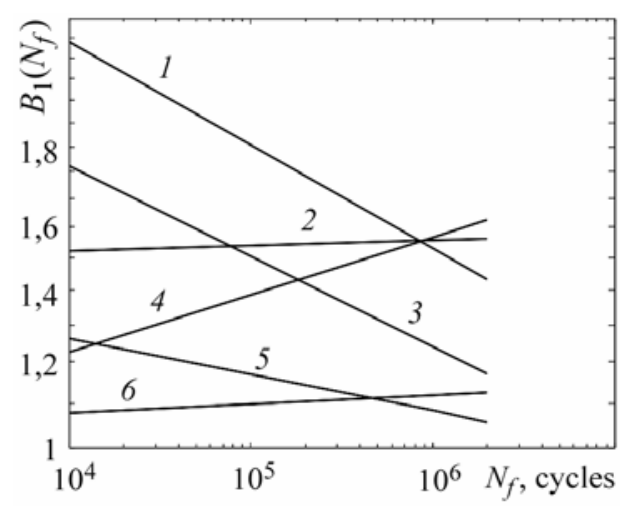

Fig. 7. Dependence of the ratio $k\left(N_{f}\right)$ on a number of cycles $N_{f}$ for high-alloy steels. $1-3.5 \% \mathrm{NiCr}$ I (hollowed); $2-3.5 \% \mathrm{NiCr}$ II; 3 -30CrNiMo8; $4-3.5 \%$ NiCr I; $5-35 \mathrm{NCD} 16 ; 6-\mathrm{NiCr}$. not be related to all the cast irons. In the case of Nicro Silal and IC2 constant value of $B_{1}\left(N_{f}\right)$ can be seen, for Silal a value of the relative difference $R$ exceeds $10 \%$. As for the second group of cast irons (Fig. $8 b$ ), we can find constant $B_{1}\left(N_{f}\right)$, so it is possible to apply $B_{1}\left(N_{f}\right)$ for the given group of cast irons. The values of the ratio $B_{1}\left(N_{f}\right)$ vary about 1 . It results from properties of cast irons which are brittle and non-ductile materials.
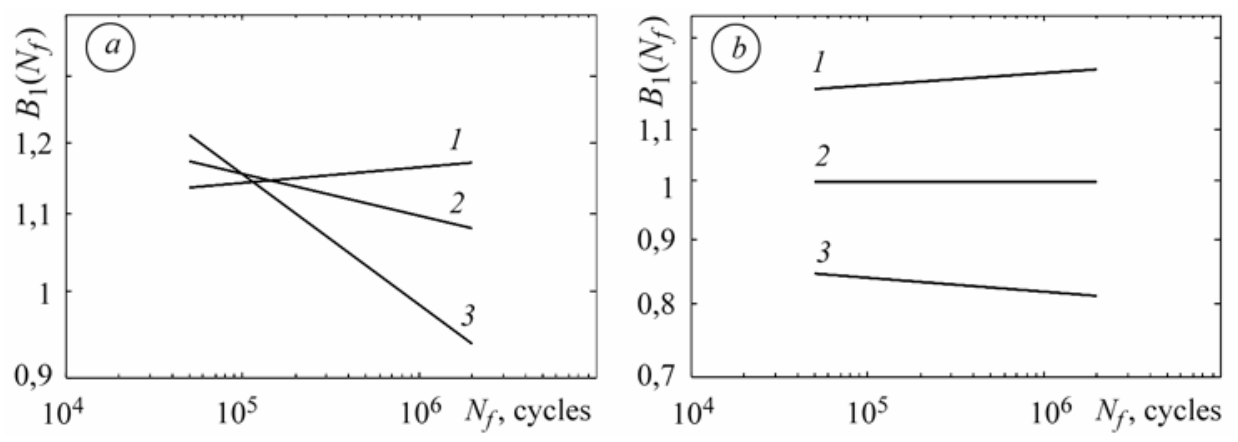

Fig. 8. Dependence of the ratio $B_{1}\left(N_{f}\right)$ on a number of cycles $N_{f}$. $a: R>5 \% ; 1-\mathrm{IC} 2 ; 2$ - Nicro Silal; 3 - Silal.

$b: R<5 \% ; 1-$ GTS $45 ; 2$ - GGG 60; 3 - GGG 40 . 


\section{CONCLUSIONS}

The conversion factors proposed by Tresca and Huber-Mises-Hencky are widely used and related to all the constructional materials for determination of strength and fatigue life of machines. In this paper the fatigue dependence $B_{1}\left(N_{f}\right)$ was determined for some chosen materials. Analyzing the graphs and values of the relative difference $R$, we can draw the following conclusions:

1. It is not possible to apply the ratio $B_{1}\left(N_{f}\right)$ for all considered non-ferrous metals. In the case of brass, a value of the ratio $B_{1}\left(N_{f}\right)$ is not constant in the given range of a number of cycles. The remaining non-ferrous metals can be characterized by the constant ratio but its value is below the Tresca and HMH conversion factors.

2 . In the case of carbon steels, a value of the ratio $B_{1}\left(N_{f}\right)$ is not constant but it varies depending on chemical composition and the applied heat treatment. Carbon steels characterized by the constant values of the ratio in the given range of a number of cycles do not reach the Tresca conversion factor 2 and the HMH conversion factor $\sqrt{3}$.

3. The ratio $B_{1}\left(N_{f}\right)$ is not constant for all the considered alloy steels. It depends on the applied heat treatment and contents of alloy additions.

4. As for cast irons, the ratio $B_{1}\left(N_{f}\right)$ in the given range of a number of cycles $N_{f}$ is close to 1 and strongly differs from Tresca and HMH conversion factors, and is characteristic for the Galileo hypothesis.

РЕЗЮМЕ. Подано огляд критеріїв багатовісної втоми, які охоплюють співвідношення нормальних та зсувних напружень. Розглянуто втомні характеристики деяких вибраних конструкційних матеріалів за згину та закруту. Визначено співвідношення нормальних до зсувних напружень для певної кількості циклів $N_{f}$ у діапазоні $5 \cdot 10^{4} \div 2 \cdot 10^{6}$. Із результатів аналізу втомних характеристик та відносної зміни $R$ виявлено, що матеріали можна поділити на дві групи, для яких доцільно чи недоцільно застосувати стале значення розглянутого в критерії співвідношення.

PЕЗЮМЕ. Дан обзор критериев многоосной усталости, которые включают соотношения нормальных и напряжений сдвига. Рассмотрены усталостные характеристики некоторых избранных конструкционных материалов при изгибе и кручении. Определено соотношение нормальных и напряжений сдвига для определенного числа циклов $N_{f}$ в диапазоне $5 \cdot 10^{4} \div 2 \cdot 10^{6}$. Из результатов анализа усталостных характеристик и относительной разницы $R$ установлено, что материалы можно разделить на две группы, для которых возможно или невозможно применить постоянное значение рассмотренного в критерии соотношения.

1. ASTM E 739-91 (1998): Standard practice for statistical analysis of linearized stress-life $(S-N)$ and strain life $(\varepsilon-N)$ fatigue data // Annual Book of ASTM Standards. - Philadelphia. - 1999. - Vol. 03.01. - P. 614-620.

2. Influence of hydrogen on the crack resistance of $10 \mathrm{Kh} 15 \mathrm{~N} 27 \mathrm{~T} 3 \mathrm{~V} 2 \mathrm{MR}$ steel / O. I. Balyts'kyi, L. M. Ivas'kevych, V. M. Mochul's'kyi, O. M. Holiyan // Materials Science. - 2009. - № 2. - P. 258-267.

3. Carpinteri A. and Spagnoli A. Multiaxial high-cycle fatigue criterion for hard metals // Int. J. Fatigue 23. - 2001. - P. 135-145.

4. Esderts A. Betriebsfestigkeit bei mehrachsiger Biege und Torsionsbeanspruchung. - Fakultat fur Berbau, Huttenwesen und Maschinenwesen der Technischen Universitat Clausthal, 9 Juni 1995. - P. 126.

5. Fakuda T. and Nisitani H. Background of Fatigue Limit Ratio of Torsional Fatigue to Rotating Bending Fatigue in Isotropic Materials and Materials with Clear - Banded Structure. - Japan, Sasebo: Department of Mechanical Engineering, Sasebo National College of Technology, 1993. - P. 857.

6. Findley $W . N$. A theory for the effect of mean stress on fatigue of metals under combined torsion and axial load or bending // J. Engng. for Industry. - 1959. - P. 301-306. 
7. Gough H. J. Some Experiments on the Resistance of Metals to Fatigue under Combined Stresses. - London: His Majesty's Stationery Office 1951. - P. 141.

8. Trwałość zmęczeniowa duraluminium PA6 w warunkach proporcjonalnego stało amplitudowego zginania ze skręcaniem / D. Kardas, K. Kluger, T. Łagoda, P. Ogonowski // XX Sympozjum Zmęczenie i Mechanika Pękania. - Bydgoszcz - Pieczyska, ATR Bydgoszcz, 2004. - S. 163-169.

9. Kohut M., Łagoda T. Badania zmęczeniowe mosiądzu MO58 w warunkach proporcjonalnego cyklicznego zginania ze skręcaniem // III Sympozjum Mechaniki Zniszczenia Materiałów i Konstrukcji, Augustów, 1-4 czerwca 2005. - Politechnika Białostocka. - S. 159-162.

10. Lee $S$. B. A criterion for fully reversed out-of-phase torsion and bending // Multiaxial fatigue ASTM STP 853. - Philadelphia, 1985. - P. 553-568.

11. Eagoda T. and Ogonowski P. Criteria of multiaxial random fatigue based on stress, strain and energy parameters of damage in the critical plane // Mat.-Wiss. u. Werkstofftech. - 2005. - 36, № 9. - P. 429-437.

12. McDiarmid D. L. Fatigue under out-of-phase bending and torsion // Fatigue Fract. Engng. Mater. Struct. - 1987. - 9, № 6. - P. 457-475.

13. Morel F. Fatique Multiaxiale Sous Chargement D'amplitude Variable. - Docteur De L'Universite De Poitiers, Futuruscope, 1996. - P. 288.

14. Muller A. Zum Festigkeitsverhalten von mehrachsig stochastisch beanspruchten Gußeisen mit Kugelgraphit und Tempergu $\beta$, Fraunhofer. - Institut fur Betriebsfestigkeit, Darmstadt 1994. - P. 103.

15. Niestony A., Sonsino C. M. Comparison of Some Selected Multiaxial Fatique Assessment Criteria. - Fraunhofer Institut fur Betriebsfestigkeit Systemzuverlassigkeit, 2008. - P. 86.

16. Nishihara T. and Kawamoto M. The strength of Metals under Combined Alternating Bending and Torsion with Phase Difference // Memoirs of the College of Engineering. - Kyoto Imperial University, 1945. - 11. - P. 85-112.

17. Pawliczek $R$. Badanie wpływu parametrów obciążenia i geometrii karbu na trwałość przy zmiennym zginaniu i skręcaniu // Rozprawa doktorska. - Opole: Politechnika Opolska, 2001. - P. 170 .

18. Seweryn A. Kumulacja uszkodzeń i pękanie elementów konstrukcyjnych w złożonych stanach obciążeń. - Białystok: Wydawnictwo Politechniki Białostockiej, 1997. - P. 183.

19. Skrzyszowski Z. Reduktor Stożkowo-walcowy. - Wydawnictwa Politechniki Krakowskiej, 2000. - P. 167.

20. Kurek M., Lagoda T., Staniczek S. Porównanie charakterystyk zmęczeniowych na zginanie i skręcanie wybranych materiałów konstrukcyjnych. Zmęczenie i Mechanika Pękania / Pod red. J. Semprucha i D. Skibickiego // Materiały XXIII Sympozjum Zmęczenia i Mechaniki Pękania. - Bydgoszcz: Wydawnictwo uczelniane Uniwersytetu Technologiczno-Przyrodniczego, 2010. - S. 81-82 CD; S. 267-276.

21. Walat K. and Lagoda T. The equivalent stress on the critical plane determined by the maximum covariance of normal and shear stresses // Met.-Wiss. u. Werkstofftech. - 2010. - 41, № 4. - P. 218-220.

22. Zenner H. and Liu J. The fatigue limit under multiaxial loading // Proc. Sixth Int. Conf. on Biaxial/Multiaxial Fatigue \& Fracture. - Lisboa. - 2001. - Vol. 1. - P. 29-39.

Received 01.10.2009 